\title{
A Community of Ants, Fungi, And Bacteria: A Multilateral Approach to Studying Symbiosis
}

\author{
Cameron R. Currie \\ Department of Ecology and Evolutionary Biology, 2041 Haworth Hall, University \\ of Kansas, Lawrence, Kansas 66045-7534; e-mail: ccurrie@ku.edu
}

Key Words actinomycetes, antibiotics, coevolution, fungus-growing ants, mutualism

- Abstract The ancient and highly evolved mutualism between fungus-growing ants and their fungi is a textbook example of symbiosis. The ants carefully tend the fungus, which serves as their main food source, and traditionally are believed to be so successful at fungal cultivation that they are able to maintain the fungus free of microbial pathogens. This assumption is surprising in light of theories on the evolution of parasitism, especially for those species of ants that have been clonally propagating their cultivars for millions of years. Recent work has established that, as theoretically predicted, the gardens of fungus-growing ants are host to a specialized, virulent, and highly evolved fungal pathogen in the genus Escovopsis. In addition, the ants have evolved a mutualistic association with filamentous bacteria (actinomycetes) that produce antibiotics that suppress the growth of Escovopsis. Thus, the attine symbiosis appears to be a coevolutionary "arms race" between the garden parasite Escovopsis on the one hand and the ant-fungus-actinomycete tripartite mutualism on the other. These recent findings indicate that microbes may be key components in the regulation of other symbiotic associations between higher organisms.

\section{CONTENTS}

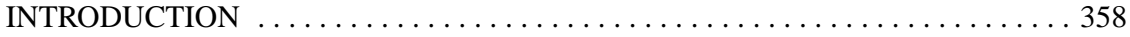

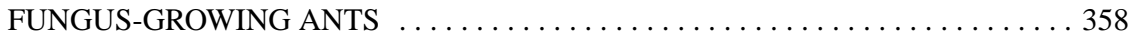

FUNGI CULTIVATED BY FUNGUS-GROWING ANTS $\ldots \ldots \ldots \ldots \ldots \ldots . \ldots 360$

COEVOLUTION BETWEEN THE ANTS

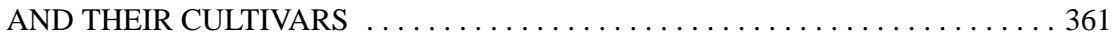

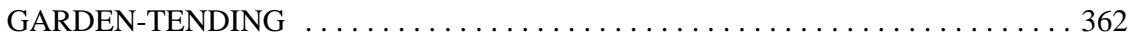

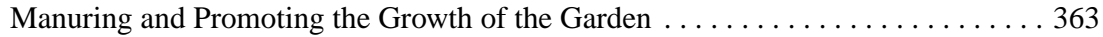

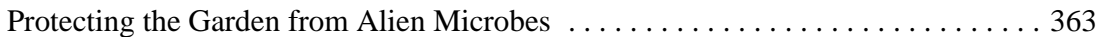

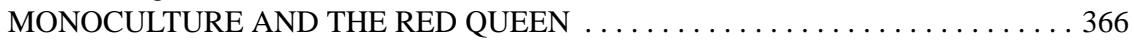

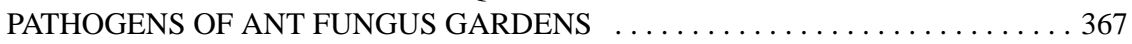

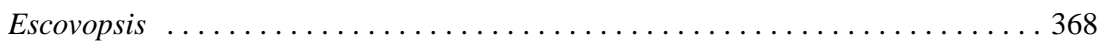

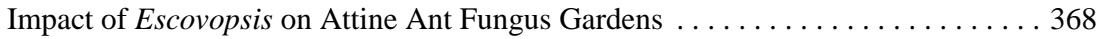

Specialist Versus Generalist Garden Pathogens $\ldots \ldots \ldots \ldots \ldots$

Taxonomy and Life History of Escovopsis . . . . . . . . . . . . . . . . . 370 


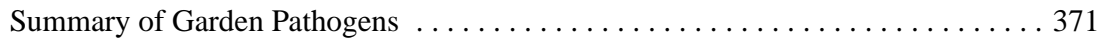

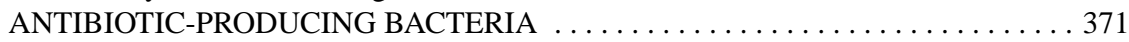

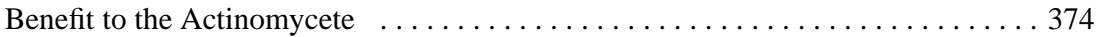

FUTURE DIRECTIONS . . . . . . . . . . . . . . . . . . . . . . . . 374

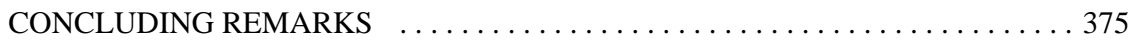

\section{INTRODUCTION}

Symbiotic associations shape the evolution of every living organism and all levels of biological organization $(3,11,12,50,51,64)$. Organisms do not occur in isolation; they live in close association with a phylogenetically diverse assemblage of other species, thereby establishing symbiosis as a ubiquitous and ecologically dominant component of the natural world. Mutualisms, for instance, once thought to be rare and therefore of limited importance (see 11,12), are now recognized as having shaped the evolution of higher life on earth. Several examples illustrating the importance of mutualism are the role of endosymbionts in eukaryotic cells, the reliance of $90 \%$ of land plants on mycorrhizal fungi for nutrients, and the dependence of many animals on microbes to aid digestion.

The study of mutualism has traditionally lagged behind that of predation and competition; however, substantially more research has focused on mutualistic associations over the past few decades. Nonetheless, Bronstein (14) points out that our understanding of mutualism has been greatly hindered because most of the studies of beneficial interactions have been unilateral in approach, focusing on only one of the two partners. This approach not only overlooks the presence of one partner, but it implies that mutualisms occur between two symbionts in isolation from all other organisms (20). In this review I examine not only the bilateral interaction between two ancient symbiotic partners (fungus-growing ants and their fungi), but also explore the interactions these mutualists have with the complex assemblage of other organisms associated with them, illustrating how a multilateral approach can result in a more complete understanding of symbiosis.

The ancient, highly evolved, obligate mutualism between fungus-growing ants (Hymenoptera: Formicidae: Attini) and their fungi (Agaricales: mostly Lepiotaceae: Luecocoprineae) is a textbook example of symbiosis. The ants carefully tend the fungus, providing it with optimal conditions for growth. In exchange, the fungus serves as the main food source for the ants. The origin of this mutually beneficial interaction was likely more than $45-65$ million years ago $(57,93)$, and the subsequent evolutionary history of this ancient mutualism has resulted in an amazing complexity of associations.

\section{FUNGUS-GROWING ANTS}

Fungus-growing ants are only New World in distribution, indicating that the origin and subsequent radiation throughout the Neotropics occurred after the separation of South America from Africa (88). The ability to cultivate fungi has a single 
TABLE 1 Genera of fungus-growing ants organized by evolutionary sequence from the most phylogenetically basal to the most phylogenetically derived $(72,90)$. The ecological characteristics of each genus are outlined, illustrating the evolutionary trend toward increasingly complex fungiculture $(34,88,93)$. The genus Pseudoatta is not included, as it is only known as a worker-less social parasite.

\begin{tabular}{|c|c|c|c|c|}
\hline Attini genera & Worker size & $\begin{array}{l}\text { Degree of worker } \\
\text { polymorphism }\end{array}$ & $\begin{array}{l}\text { Colony } \\
\text { size }\end{array}$ & $\begin{array}{l}\text { Garden } \\
\text { substrate }\end{array}$ \\
\hline \multicolumn{5}{|l|}{ Lower attines } \\
\hline Myrmicocrypta & Small & Monomorphic & $\begin{array}{l}\text { Small to } \\
\text { medium }\end{array}$ & Insect corpses \\
\hline Mycocepurus & Small & Monomorphic & Small & Insect feces \\
\hline Apterostigma & $\begin{array}{l}\text { Small to } \\
\text { medium }\end{array}$ & Monomorphic & Small & $\begin{array}{c}\text { Insect feces and } \\
\text { woody matter }\end{array}$ \\
\hline Mycetarotes & Small & Monomorphic & Small & Unknown \\
\hline Mycetosoritis & Small & Monomorphic & Small & $\begin{array}{l}\text { Dead vegetative } \\
\text { matter }\end{array}$ \\
\hline Cyphomyrmex & Small & Monomorphic & Medium & $\begin{array}{l}\text { Insect feces, } \\
\text { corpses }\end{array}$ \\
\hline Mycetophylax & Small & Monomorphic & Small & Dead grass \\
\hline \multicolumn{5}{|l|}{ Higher attines } \\
\hline Sericomyrmex & Medium & Monomorphic & Medium & $\begin{array}{l}\text { Dead vegetative } \\
\text { matter }\end{array}$ \\
\hline Trachymyrmex & Medium & $\begin{array}{l}\text { Slightly } \\
\text { polymorphic }\end{array}$ & Medium & $\begin{array}{l}\text { Dead vegetative } \\
\text { matter }\end{array}$ \\
\hline \multicolumn{5}{|l|}{ Leaf-cutters } \\
\hline Acromyrmex & $\begin{array}{r}\text { Medium } \\
\text { to large }\end{array}$ & Polymorphic & Large & $\begin{array}{r}\text { Fresh leaves } \\
\text { and flowers }\end{array}$ \\
\hline Atta & Large & $\begin{array}{l}\text { Strongly } \\
\text { polymorphic }\end{array}$ & $\begin{array}{l}\text { Very } \\
\text { large }\end{array}$ & $\begin{array}{c}\text { Fresh leaves } \\
\text { and flowers }\end{array}$ \\
\hline
\end{tabular}

origin in ants $(72,90)$, evolving from an ancestor that is believed to have been a generalist forager (57). The ants belong to the monophyletic tribe Attini (subfamily Myrmicinae), which is composed of 12 genera and approximately 210 described species (72; Table 1). The five most phylogenetically derived genera form a clade called the "higher attines," and the remaining seven genera, with approximately half of the species diversity, compose the "lower attines." Although all attine ants are referred to as fungus-growers, the two most phylogenetically derived genera, Acromyrmex and Atta, are more commonly known as leaf-cutter ants. The lower attines typically use dead vegetative debris as well as insect feces and corpses to manure their gardens; the higher attine genera Trachymyrmex and Sericomyrmex typically use dead vegetable matter, whereas those of the genera Acromyrmex and Atta use mostly fresh leaves and flowers (Table 1).

Fungus-growing ants are obligately dependent on their fungal cultivars. The fungus serves as the sole food source for the larvae and queen, while workers 
supplement this by feeding on plant sap $(42,59,67)$. The general nutritional value of the fungi that the attine ants cultivate is not clear (see 57); however, the fungi cultivated by many members of the higher attines produce specialized structure called gongylidia that the ants preferentially feed on $(52,66,87,88)$. Gongylidia are hyphal swellings that, at least among the fungi cultivated by leaf-cutters, are rich in lipids and carbohydrates $(47,67)$.

Fungus-growing ants, like all ants, are social, forming colonies of closely related individuals. Ant colonies have been described as "superorganisms" (34), with individual workers performing tasks for the functioning of the colony just as cells in higher organisms. The queen, of which there is usually only one, tends the garden in its incipient stage and subsequently reproduces the worker population; workers engage in tasks that help the colony function, such as foraging for food, cleaning the nest, caring for the brood, and defending against attackers; and males participate only in reproduction, dying shortly after the nuptial flight.

The queen transfers the fungus into the next generation by carrying a small clump of the cultivar with her during the nuptial flight $(35,36)$. This ball of fungus from the parent colony is stored in the queen's infrabuccal pocket, a cavity and filtering device within the mouthparts of ants (27). Once inseminated, the queen typically digs a claustral chamber, spits-up the fungus, and begins tending it underground, although some species form new colonies under leaf litter or rocks, under or within logs, or even in trees (88). Prior to the presence of workers, growth of the fungus is supported by the foundress queen, who either forages for substrate or uses fecal fluids to manure the garden (depending on the species). The queen tends the new garden until the first brood of workers has been reared, at which point workers take over the tasks of tending the fungal cultivar and foraging for garden substrate.

The colony continues to accumulate biomass of both ants and fungus until reaching sufficient size to produce new reproductive individuals. Colonies typically are perennial, living for many years and producing reproductives annually until the queen dies. Among the lower attines, colony and worker size are typically small, with no worker polymorphism. There is an apparent evolutionary trend toward greater colony and worker size as well as worker polymorphism from the lower to higher attines $(34,91,93$; Table 1$)$. This trend finds its culmination in the leafcutter genus Atta, which can have colonies with millions of workers, can live for more than 10 years, and has strong worker polymorphism $(87,88)$.

\section{FUNGI CULTIVATED BY FUNGUS-GROWING ANTS}

An understanding of this mutualism has been greatly hindered by the lack of information regarding the taxonomic placement and evolutionary history of the fungal cultivars. The traditional methods for fungal taxonomy and systematics depend on the morphology of fruiting structures; however, the fungi cultivated by attine ants do not readily produce these sexual structures in association with 
the ants or in pure culture $(31,52,55)$. Although there generally has been a consensus that the fungi are basidiomycetes, likely in the order Agaricales $(52,88)$, definitive generic identification was not possible prior to the recent development of molecular phylogenetic techniques. With the use of this technology, it has been established that most of the fungi belong to the family Lepiotaceae (Basidiomycota: Agaricales), in the tribe Leucocoprineae $(16,32,56)$. This tribe is composed of two genera, Leucocoprinus and Leucoagaricus. Members of the Leucocoprineae are mostly tropical species that are specialized litter decomposers $(25,76)$. An extensive study by Mueller and colleagues (56) indicates that there are at least two distinct clades of leucocoprineous fungi that are cultivated by fungus-growing ants and, as I discuss below, the dynamics of the association between the ants and their fungi are complex. In contrast to most attines that cultivate fungi in the family Lepiotaceae, some ant species in the genus Apterostigma cultivate fungi in the family Tricholomataceae (16). These cultivars appear to be closely related to the wood decomposing fungi in the genus Gerronema (53).

\section{COEVOLUTION BETWEEN THE ANTS AND THEIR CULTIVARS}

Because fungus-growing ant queens carry fungal inocula from their parent to their new colonies (i.e. vertical transmission), the ants and their fungal cultivars are both descendants of symbionts that were associated in the previous generation. It traditionally has been assumed that the evolution of the mutualism between attine ants and their cultivars has been shaped by this "vertical transmission" of cultivars $(87,88)$. Strict clonal propagation of the cultivars through vertical transmission would suggest that the fungal cultivars are ancient clones and that there is a strong congruence between the evolutionary history of the ants and their fungal cultivars (i.e. each species of ant cultivating a distinct species of fungus). It would also be expected that cultivars of closely related ants should be closely related, whereas cultivars of distantly related ants should be distantly related. However, recent work has established that ant-fungus evolution is much more complicated than previously assumed, involving a diverse assemblage of distantly related fungi and distinct patterns of evolution occurring within different groups of fungus-growing ants $(16,56)$.

Mueller et al (56) conducted an elaborate study examining the evolutionary history of fungi cultivated by lower attines, specifically members growing leucocoprineous cultivars (i.e. not those species of Apterostigma that grow fungi in the Tricholomataceae). They sampled extensively across the 7 genera of the lower attines and a wide geographic region, obtaining more than 553 isolates of fungi. In addition, they collected and cultured 309 free-living members of the Leucocoprineae that were suspected to be the closest free-living (not occurring in association with fungus-growing ants) relatives to the cultivars of the lower attines. Then, using population genetic techniques and sequencing of conserved 
genes, they examined the coevolution between the ants and fungi both within and between ant genera and concluded the following: (a) Within the same population, distantly related ant species may cultivate the same fungal clone, and $(b)$ the same ant species (or perhaps species complex) may cultivate distantly related cultivars. These two findings indicate that fungus-growing ants, at least in the lower attines, are able to acquire new cultivars through a process of lateral transfer (switching of cultivars between ant colonies).

Mueller et al (56) also found that some of the fungi cultivated by these lower attine ants are very closely related to, or perhaps are even isolates of the same clones as, free-living counterparts of ant-cultivated fungi. Finding free-living and fungusgrowing ant-associated fungi that are apparently genetically identical may be the result of a recent domestication of the fungus by the ants. Therefore, the findings from Mueller et al suggest that the acquisition of new fungal cultivars within this mutualism is a continuous process in at least the more primitive form of fungus-growing ants. The alternative explanation for this finding is that instead of being recently domesticated, the free-living fungus escaped from its symbiotic association with ants to return to a free-living existence. This is perhaps less likely, but has not been ruled out completely.

The detailed ant-cultivar evolutionary history still needs to be analyzed for the higher attines. However, based on the work of Chapela et al (16) and Hinkle et al (32), it is clear that the evolutionary history is a much closer approximation of the assumed strict coevolution between the ants and their fungi. In fact, it appears that the fungi cultivated by the higher attine ants are ancient clones that have been evolving strictly within this mutualism for millions of years. These fungi form a monophyletic clade likely derived from the leucocoprineous fungi cultivated by the lower attines (16).

Therefore, ant-fungus evolution among the lower attines is shaped by vertical transmission of the fungus from parent to offspring colony, with occasional horizontal (lateral) transfers of cultivars between ant colonies and perhaps domestication of novel cultivars. In contrast, it appears that among the higher attines the fungi cultivated are ancient asexual clones with no domestication of novel cultivars from free-living fungi, resulting in much greater congruence between the ants and their fungi than that found among the lower attines.

\section{GARDEN-TENDING}

Fungiculture by attine ants begins with the collection of substrate upon which to grow the fungus. As mentioned above, the substrate utilized by these ants is varied (Table 1), and it is likely that garden-tending behaviors vary between the different genera $(58,59,88)$. However, most studies of how fungus-growing ants tend their gardens have focused primarily on the derived leaf-cutters. Here I overview the current understanding of how the two leaf-cutter genera, Acromyrmex and Atta, cultivate fungi. 


\section{Manuring and Promoting the Growth of the Garden}

Once the substrate is brought back to the colony, the ants begin the decomposition process by licking and then masticating the leaf material, breaking it into pieces as small as 1-2 $\mathrm{mm}$. The breakdown of the vegetative material is a crucial step in the culturing of the fungus for several reasons. First, it likely helps eliminate some of the microbes present in the leaf material that could out-compete or parasitize the ants' fungal cultivars (65). Second, leaf surfaces form a physical barrier against fungal invasion (2), so masticating the material promotes the establishment of the ants' cultivar on the substrate. Finally, this process may be important in promoting the breakdown of the leaf material by increasing the surface area and edges.

The resulting pulp is sometimes applied with a fecal droplet, which is believed to add important enzymes that help the fungus break down the material (see below). The pulp is then brought to the top of the garden and worked into position. At this stage, fungal inoculum from older parts of the garden is planted onto the surface of the fresh substrate. It takes approximately six weeks for the vegetative material to be completely broken down by the fungus. During this time fresh material is added to the top of the garden, leading to a continuous cycling of material such that the oldest substrate lies at the bottom. The spent material is removed from the bottom of the garden and placed in the refuse heap. The refuse is typically not in close proximity to garden chambers, but rather is deposited in special underground dump chambers or outside the colony, depending on the ant species. Because refuse heaps of leaf-cutter ants are hazardous to the health of both the ants and their garden due to an apparent build-up of pathogens, ants deal with refuse in a manner that reduces the colony's exposure to this material (10a).

There is much more involved in cultivating fungus gardens than adding substrate and recycling fungus. In fact, throughout this process workers are continuously promoting the growth of the fungus. One means of growth promotion employed by the ants is to move proteolytic enzymes around the garden, from areas of high concentration to areas of low concentration $(44,45,47)$. Interestingly, these enzymes are apparently produced by the fungus and are subsequently ingested by the ants and then defecated onto needed locations (13). An additional means of growth promotion has been suggested by Bass \& Cherrett (8), who provide evidence that the ants mechanically damage the fungal hyphae to stimulate their growth, perhaps in effect pruning them. The ants also optimize the climatic conditions for the fungus by opening or closing tunnels to the surface, thus regulating the temperature and humidity within the colony (88).

\section{Protecting the Garden from Alien Microbes}

Cultivating fungi requires complex behavioral and physiological adaptations (such as those outlined above); however, the ability of attine ants to maintain healthy fungus gardens is usually described as the most important adaptation. Fungus gardens are continuously inoculated with bacteria and fungi from the substrate added to the garden $(87,88)$, and most of these microbes are superior competitors to the 
fungi cultivated by the ants (66 C.R. Currie, unpublished data). Establishing how the ants protect their gardens from alien microbes is fundamental to understanding this ant-fungus mutualism. However, while some mechanisms have been hypothesized to be employed by the ants to rid the garden of invading microbes, little empirical evidence supports most of these hypotheses.

PROMOTING THE COMPETITIVE ABILITY OF THE CULTIVAR Neil Weber, who studied fungus-growing ants for almost five decades, argues in his 1972 monograph on attine ants that the primary mechanism for maintaining healthy fungus gardens involves the provision of optimum growing conditions for the fungus (as outlined above). This is believed to allow the ants' cultivar to out-compete other microbes present in the garden. However, there is currently no evidence that such promotion of their own cultivars suppresses growth of, and invasion by, alien microbes. In fact, some allochthonous microbes would be expected to benefit from the optimal growing conditions that are provided by the ants. In addition, most of the methods thought to be employed by the ants to promote the growth of their fungal cultivars have not been demonstrated to occur among attine ants outside of the leaf-cutters. However, the optimization of growing conditions by the ants should not be entirely discounted. Perhaps the most significant activity in this regard is the inoculation of the substrate with a large biomass of fungus, which would greatly improve the competitive advantage of the ants' fungus.

PRODUCTION OF ANTIBIOTICS BY ATTINE ANTS It has generally been assumed that the ants suppress alien microbes within their gardens through the production of antibiotics in their metapleural glands (see e.g. 16, 61). The metapleural glands are paired structures located on the posterolateral edge of the metathorax. The evidence used to support this hypothesis is the presence within these glands of compounds with antimicrobial properties $(48,60,69,70)$. The metapleural glands in Atta primarily produce phenylacetic acid, but also 3-hydroxydecanoic (myrmicacin) and indoleacetic acid, which likewise have been demonstrated to be present in the metapleural glands of Acromyrmex $(48,60,69)$. Applying new techniques, Ortius-Lechner et al (62) were able to detect many additional compounds within the metapleural glands of Acromyrmex that had been overlooked previously, some with antibiotic properties. However, as pointed out by Hölldobler \& Engel-Siegel (33), demonstrating the antibiotic activity of these compounds is not sufficient for establishing that the glands have an antiseptic function. Furthermore, metapleural glands that produce compounds with antibiotic activity are not unique to fungusgrowing ants but are present in most ants, suggesting a common, basic function not associated with the cultivation of fungi $(9,10,33,82)$. In order to demonstrate that the metapleural glands of attine ants help maintain the health of the garden, Weber $(88,89)$ contends that it is necessary to establish that the compounds from these glands are present within the garden at a sufficient level to suppress microbes. This, however, has not been accomplished. In addition, it is important to establish that antimicrobial compounds are active against ecologically relevant microbes 
(i.e. ones that actually would invade and grow in fungus gardens). In most of the bioassays conducted in the experiments discussed above, the microbes studied have not been shown to be ecologically relevant.

It has also been suggested that fungus-growing ants produce antibiotics in their mandibular glands (40). These glands are associated with the mouthparts of ants, and thus, antibiotics produced within them could more readily be applied to the garden by the ants than those produced in the metapleural glands, which are located on the posterior surface of the ants. Nevertheless, establishing a garden-defense role for the mandibular glands requires the same evidence outlined above for the metapleural glands. However, as with the metapleural glands, the requisite empirical evidence is lacking. Thus, it cannot be assumed that either the metapleural or mandibular glands have a role in protecting the gardens of fungus-growing ants.

ANTIBIOTICS PRODUCED BY THE FUNGAL CULTIVARS It has also been argued that the fungus itself produces antibiotics that help protect it from competitors or parasites. Several studies have addressed this possibility with mixed results. Martin and colleagues (46), Weber (88), Hervey et al (31), Papa \& Papa (63), and Stradling $\&$ Powell (80), examining fungi cultivated by leaf-cutter ants, found no antifungal activity in the fungal symbiont. Only Angeli-Papa (4) found any evidence of the leaf-cutter cultivar producing antibiotic substances. In contrast, Hervey \& Nair (30) and Wang et al (84) found that some fungi cultivated by lower attine ants produce compounds with antimicrobial properties. It is now clear that a diverse assemblage of fungi are cultivated by attine ants $(16,56)$, so it would not be surprising to find that some clades of fungal cultivars produce antibiotics, whereas others do not. In any case, antibiotic production by the ant cultivars may be more important than has been assumed to date.

LICKING AND WEEDING OF MICROBES BY WORKERS It also has been hypothesized that fungus-growing ants maintain the health of their fungus gardens by workers physically removing alien microbes through two primary methods: licking and "weeding." Licking and masticating of leaves, as mentioned above, appears to decrease the abundance of microbes entering the garden on the substrate (65). In addition, fungus-growing ants engage in licking all nest surfaces with their tongues and frequently groom themselves and each other $(5,65,67,77)$. Finally, workers are frequently observed licking the garden, and it has been suggested that this behavior eliminates microbes that come in contact with the garden (7). The weeding of microbes by workers has also been assumed to be fundamental to the health of the garden. Support for this assumption is drawn from an abstract published by Neil Weber (86). However, no empirical data are presented in this abstract, and Weber (88) himself later indicated that he "no longer considered [weeding] important." Currie and Stuart (24a) experimentally infected colonies of leaf-cutter A. colombica to examine the ability of workers to physically remove invading microbes. They found that the ants engage in two primary behavioral defenses: the physical removal of microbes through grooming of alien spores from the fungus 
garden and the removal of infected parts of the garden (termed fungus grooming and weeding, respectively). Further work is required to examine the importance of these behaviors among other fungus-growing ants.

FUNGUS GARDENS AS MONOCULTURES Despite the fact that our understanding of how the ants defend their gardens from alien microbes is incomplete, biologists have assumed that the ants maintain their mutualist in pure "monocultures," preventing other microbes and parasites from occurring in the garden (see e.g. $28,61,85,87,88)$. There is little evidence to support this assumption. Those arguing that the garden is maintained axenically (in pure culture) have used as evidence the hypothesized methods the ants employ to eliminate alien microbes (e.g. $61,87,88)$. Even the observation that gardens are rapidly overgrown by alien fungi in the absence of the ants has been used to support the claim that the gardens are monocultures (see e.g. 28, 87, 88). Nevertheless, the presumed absence of garden pathogens is theoretically surprising, as I outline below.

\section{MONOCULTURE AND THE RED QUEEN}

In parasitic associations, the interests of the parasite and its host are opposed, such that any attempt by a parasite to increase its net benefit should be counteracted by its host defending against exploitation. This results in each symbiont evolving in response to the other in a process called coevolution. When symbionts coevolve in a series of escalating adaptations and counter-adaptations, with each symbiont continuously adapting to the selective pressure exerted on it by the other, the symbionts are engaged in what may be referred to as a "coevolutionary arms race." The locking of symbionts into an escalating coevolutionary arms race has been called the "Red Queen" theory, referring to Lewis Carroll's Through the Looking Glass, in which Alice and the Red Queen have to continuously run faster and faster to stay in the same place (81).

The Red Queen theory was later adapted by Jaenike (37) into a hypothesis to explain the selective force that maintains the dominance of sexual reproduction. It is commonly recognized that asexual organisms can propagate their genes twice as quickly as their sexual conspecifics $(49,92)$. Considering the competitive advantages of asexual reproduction, some selective force must favor sexual reproduction. Many theories have been generated to explain the dominance of sex; however, one of the most promising is the Red Queen hypothesis, which suggests that sexual reproduction is an advantage for organisms in their coevolutionary arms race with parasites. This hypothesis is based on the belief that parasites are able to rapidly adapt to asexual or genetically homogenous hosts. Only by obtaining new or novel resistant genotypes through the process of sexual recombination can hosts stay ahead in the coevolutionary arms race with their parasites. Thus, based on the Red Queen hypothesis, it is predicted that fungus-growing ants, especially the higher attines that apparently cultivate ancient asexual clones, should 
experience serious parasite pressure. Insight from human agriculture provides additional evidence of this, as attempts to cultivate genetically homogenous cultivars have resulted in problems with pathogens $(6,43)$. In fact, examples from human agriculture have been used as partial evidence to support the Red Queen hypothesis $(26,74)$.

\section{PATHOGENS OF ANT FUNGUS GARDENS}

Möller (52) made the first observations suggesting that the gardens of fungusgrowing ants are hosts to pathogens. He noted that colonies maintained in the laboratory occasionally had their gardens overgrown by a fungus. However, he mistakenly assumed that what he was observing was not a pathogen or contaminant, but the anamorphic stage (asexual form) of the ants' fungus growing out of control. At the time of his work, the concept of teleomorphs (sexual form) and anamorphs was still being developed, likely facilitating this mistake. Ant-tended gardens being overgrown by alien fungi have been observed by others $(78,87,89)$; however, these observations were made on colonies maintained in the laboratory, and the fungi involved were not identified. Therefore, it has been generally assumed that the overgrowth of gardens by alien microbes occurs only in the artificial conditions of the laboratory and that the fungi involved are airborne contaminants.

The first attempt to empirically test for the possible presence of nonmutualistic fungi within gardens was made by Craven et al (19). They used dilution plating techniques and scanning electron microscopy to examine gardens for nonmutualistic microbes in colonies of Acromyrmex octospinosus and Atta cephalotes, two common leaf-cutter ant species. An abundance of yeasts and some bacteria were noted, but they only sampled from a single garden of each species and did not identify the isolated microbes. It is not clear whether these colonies were recently collected from the field or were maintained under laboratory conditions for a significant period before the isolations were conducted. A recent study also isolated yeasts from leaf-cutter ant fungus gardens (15). However, these gardens had been maintained in the laboratory for six months prior to the study, suggesting the possibility that the yeasts were present only because the laboratory provides growth conditions for the garden that are less optimal than those found in the field.

In another study Fisher and colleagues (28) examined nonmutualistic filamentous fungi within ant fungus gardens. They sampled from three Atta cephalotes colonies collected in Trinidad, but only one of these colonies was sampled in the field; the remaining two were maintained in the laboratory for months prior to sampling. They isolated mostly well-known endophytic and epiphytic fungi, which they admit were brought into the garden in the leaf material fed to laboratorymaintained colonies. Although these studies indicate that nonmutualistic microbes can invade the gardens of attine ants, they fail to establish the presence of any microbe that might be a pathogen. 


\section{Escovopsis}

Currie et al (23) conducted the first extensive study of nonmutulastic filamentous fungi associated with fungus-growing ant gardens. They examined the gardens of 201 colonies from 8 attine genera, including both lower and higher attines, occurring in the canal region of central Panama. These colonies were sampled immediately following their collection in the field, and multiple isolations were made from throughout each garden. More than 2400 garden pieces $\left(\sim 3 \mathrm{~mm}^{3}\right)$ were sampled. The frequency of contaminants was found to vary depending on the ant genus, but on average $39.7 \%$ of garden pieces sampled had at least one alien fungus present. Fungi in the hyphomycete genus Escovopsis (anamorph allied with Hypocreales: Ascomycota) were found to be the most common nonmutualistic fungi present (26\% of all contaminants). The frequent isolation of Escovopsis from the gardens of attine ants suggests it might be a pathogen. However, these fungi could likewise represent passive occupants having little or no importance within gardens, occurring as ungerminated inocula that grow only when removed from the colony and placed on nutrient agar. To clearly establish that any fungus has an important role within the gardens, it is necessary to establish that it is not only present, but that it also grows within the garden, perhaps at the expense of the fungal mutualist. It is also important to fulfill Koch's postulates of pathogenicity (2).

Multiple lines of evidence illustrate that Escovopsis is a pathogen of the fungus gardens of attine ants. First, Escovopsis is common in fungus gardens in the field (23). Second, Currie et al (23) established that Escovopsis is able to maintain a continuous presence within fungus gardens for many months. Because measures were taken to prevent these colonies from being re-infected with Escovopsis, the prolonged presence of the fungus indicates that it is growing within the gardens. If Escovopsis only occurred within the gardens as ungerminated spores, these inocula would pass through the garden in six weeks, the approximate time it takes material added to the top of gardens to cycle to the bottom. Third, removal of workers from Escovopsis-contaminated fungus gardens invariably leads to rapid overgrowth (as quickly as 12-24 hours) of the garden by this fungus (23). Fourth, the fungus can have a significant impact on the health and survivorship of the fungus gardens (20, 21, 23; see below). Fifth, all of Koch's postulates of pathogenicity have been fulfilled (23; see above). Thus, the evidence clearly demonstrates that the ants do not maintain their gardens axenically, as previously assumed, but rather gardens are host to at least one pathogen: fungi in the genus Escovopsis.

\section{Impact of Escovopsis on Attine Ant Fungus Gardens}

Escovopsis can have a dramatic impact on the health and survivorship of fungusgrowing ant gardens. As previously noted, Escovopsis can rapidly overgrow gardens in the absence of the ants (23). More importantly, however, under some conditions, even in the presence of the ants, it can completely devastate colonies by rapidly overgrowing the whole fungus garden. Dozens of colonies in the laboratory and several in the field have been observed to be completely devastated by this 
this fungus (23; C.R. Currie, unpublished observation) (Figure 1). In fact, based on illustrations and descriptions by Möller $(52)$ and others $(87,88)$ it is clear that the fungus they observed to devastate attine-ant gardens was Escovopsis.

Experimental work on leaf-cutter ants has provided further evidence that Escovopsis is a virulent pathogen. In one experiment 9 of 16 colonies of the leaf-cutter Atta colombica that were treated with heavy doses of Escovopsis spores lost their garden within 3 weeks of treatment (23). Although rapid overgrowth of the garden by Escovopsis is its most conspicuous effect on colonies, this may be far less important than the more discrete impact the pathogen typically has on this mutualism. As previously noted, Escovopsis can form a persistent infection (23), and its presence results in a significant reduction in the growth rate of the infected colony in terms of biomass of both the fungus and the ants (21). Because a large biomass of fungus garden is required to support the production of reproductive alates (both virgin queens and males), a reduction in cultivar growth could have a dramatic impact on the fitness of infected colonies by causing a delay in reaching sufficient size to reproduce. In fact, some colonies infected with Escovopsis experience a net loss in biomass over time, which suggests this pathogen may prevent some colonies from ever reaching sufficient colony size to produce new reproductives (21; C.R. Currie, unpublished results). If a colony is unable to eliminate Escovopsis, the infection may lead to the gradual loss of the colony's entire garden biomass, which eventually will result in the death of the colony or will force workers to attempt to obtain new cultivars from neighboring colonies. Thus, devastation of the fungus gardens by Escovopsis may result in the lateral transfer of cultivars between colonies (1, 56).

\section{Specialist Versus Generalist Garden Pathogens}

Several findings indicate that Escovopsis is specialized on the gardens of fungusgrowing ants. First, in addition to being the most common nonmutualistic fungus, Escovopsis has been isolated only from habitats associated with fungus-growing ants, including the fungus garden and refuse piles (10a, 23, 75). Also, Escovopsis is very common in attine colonies, having been isolated from a range of $33-75 \%$ of the more than 200 colonies sampled in Panama (depending on the ant species and the geographic location) (23). The virulence of Escovopsis (see above) within the gardens of fungus-growing ants likewise suggests it is specialized on this habitat, because generalist, unspecialized fungi have little or no impact on the health of colonies. Currie et al (23) sprayed gardens with Trichoderma sp., which despite being a very aggressive necrotrophic fungal pathogen, had little or no impact on the health of gardens. This finding indicates that the ability to infect fungus gardens requires specialized and apparently highly evolved adaptations to overcome the defenses of the ants (22).

The status of Escovopsis as a specialist pathogen of fungus-growing ant gardens is further supported by its apparent ancient association with these ants and their fungal cultivars. Several findings point to such a prolonged association. First, Escovopsis appears to occur throughout the geographic range of the mutualism, 
having been isolated from fungus-growing ant colonies in Brazil, Costa Rica, Cuba, Ecuador, Guyana, Panama, Texas, and Trinidad (23, 41, 54, 75; C.R. Currie, unpublished results). In addition, this fungus is associated with the phylogenetic diversity of the ants, having been found associated with the phylogenetically basal genera (i.e. Myrmicocrypta, Mycocepurus, and Apterostigma) to the phylogenetically derived leaf-cutter ants (i.e. Acromyrmex and Atta). Based on both morphological and molecular phylogenetic evidence, the species of Escovopsis that occur in the basal genera are a distinct clade from those that occur in the higher attines (C.R. Currie, unpublished observation). This suggests that Escovopsis has a long coevolutionary history with the ants and their fungal cultivars.

\section{Taxonomy and Life History of Escovopsis}

As noted above, Möller (52) was the first to observe fungi that would later be described in the genus Escovopsis. In his 1893 monograph, he drew the micromorphological characters of what appear to be several species in this genus. This fungal genus was first described as Phialocladus by Kreisel (41), who isolated a strain from a nest of Atta insularis in Cuba. Muchovej \& Della Lucia (54) later determined the name Phialocladus to be invalid and renamed the genus Escovopsis. They named the type species E. weberi after Neil Weber. Another species of Escovopsis was later isolated from a nest of Trachymyrmex ruthae (75). This fungus produces globose phialide-bearing vesicles, thus having an appearance similar to that of the well-known genus Aspergillus, leading Seifert and colleagues (75) to name it E. aspergilloides. These are the only two described species in this genus; however, this is only a small example of the species diversity (C.R. Currie, unpublished data).

The basic life history of Escovopsis is not well known. As previously noted, this fungus has only been isolated from the gardens of fungus-growing ants and their associated refuse heaps. The fungus grows within the fungus garden and apparently does not produce spores within the garden matrix unless it has completely overwhelmed the colony (C.R. Currie, unpublished results). Within the gardens of the leaf-cutter A. colombica the fungus is most abundant in the bottom (older) portion of gardens (21). Escovopsis readily sporulates in the refuse piles, in both the laboratory and the field. Nevertheless, most of the life cycle of this fungus still needs to be worked out.

How Escovopsis is dispersed from infected to uninfected colonies is likewise unclear, but some dispersal methods have been ruled out. Escovopsis produces wetspores and is therefore not air dispersed. Furthermore, Escovopsis is not present in the garden material carried in the infrabuccal pocket of foundress queens during their nuptial flights, nor is it present in the newly established gardens of incipient colonies (23). However, it was found to be present in more than $50 \%$ of 1 - to 2-year-old colonies from the same population, indicating that it is not vertically transmitted (i.e. from parent to offspring colonies). Thus, it appears that Escovopsis is vectored between colonies, perhaps by one (or several) of the many species of invertebrates that live in close association with fungus-growing ants $(34,88)$. 
These invertebrates, unlike the ant workers themselves, occasionally move between colonies and thus could potentially be carrying Escovopsis with them. An additional possibility is that Escovopsis has another life history stage that is involved in dispersal.

One of the fundamental questions regarding the biology of Escovopsis is the mechanism of its pathogenicity within ant fungus gardens. Is Escovopsis a highly evolved "weed," out-competing the ants' fungus for the substrate of the garden? Or is Escovopsis a "mycoparasite," obtaining its nutrients directly from the cultivated fungus? Preliminary work suggests that it is a mycoparasite; bioassays between these two fungi result in Escovopsis rapidly overgrowing the cultivated fungus, leaving no visible presence of the latter (C.R. Currie, unpublished data). However, the ants' fungus may not be broken down in order to be consumed but instead to eliminate it as a competitor for the substrate (interference competition). Perhaps Escovopsis is both a mycoparasite and a weed, obtaining nutrients from both the ants' fungus and the substrate.

It also currently is not clear whether Escovopsis has a teleomorphic (sexual) stage. Attempts to promote fruiting of Escovopsis in culture and within gardens have been unsuccessful (C.R. Currie, unpublished data). In addition, the sexual stage has not been observed in association with fungus-growing ants in the field. It is possible that Escovopsis does not have a teleomorph; however, much more research is needed. Refuse piles and/or colonies that are completely overgrown by the parasite in the field are promising locations in which a sexual stage may be discovered.

\section{Summary of Garden Pathogens}

The gardens of fungus-growing ants are parasitized by fungi in the genus Escovopsis. This fungus is a highly evolved and specialized parasite of the ant-fungal symbosis, supported by the findings that $(a)$ it is very common within and between colonies, $(b)$ it has the capacity to completely overwhelm the gardens (killing the colony), $(c)$ it is unknown from any other habitat, $(d)$ it grows within the garden matrix, and $(e)$ colonies infected with the parasite have much slower fungus garden growth rates than uninfected colonies. The discovery of Escovopsis clearly indicates that the ants do not maintain their gardens free of disease and suggests that other microbial pathogens are likely present within the gardens of these ants. In addition, it raises the question of how the ants and their fungal mutualists defend themselves against this virulent pathogen.

\section{ANTIBIOTIC-PRODUCING BACTERIA}

A few biologists have noted that some fungus-growing ant species are covered in a whitish granular deposit, which was thought to be a crystalline wax produced by the ants (88). It has recently been established that this "whitish bloom" is not a wax, but is instead a thick growth of filamentous bacteria (24; Figure 2a). 
Currie and colleagues (24) found it associated with all 22 species of fungusgrowing ants examined, representing 8 genera and the phylogenetic diversity of the Attini. They also found the bacterium associated with all colonies that were examined closely. The abundance of the bacterium on workers can be substantial, completely covering the surface of some ants, especially in the genera Trachymyrmex and Acromyrmex (Figure 2b). However, in most situations it is associated with specific regions of the ants' body. For example, in the most "primitive" (phylogenetically basal) genera, Apterostigma and Myrmicocrypta, the bacterium is located under the forelegs (Figure $2 c$ ). In the higher attine genera, Trachymrmex and Acromyrmex, the bacterium is most concentrated on the laterocervical plates of the propleura, structures located immediately posterior to the mouthparts on the ventral surface of the ants (Figure $2 d$ ). The fungus-growing antassociated actinomycete appears to be exclusively vertically transmitted (from parent to offspring colony), with queens carrying it with them on their cuticle during the nuptial flight. The bacterium is abundant on virgin queens but does not appear to be present on males, at least not in species in either Trachymyrmex or Acromyrmex (24; C.R. Currie, unpublished results). These findings, in combination with the fact that actinomycetes are well known for their ability to produce potent antibiotics $(29,83)$, led to the hypothesis that these filamentous bacteria might produce antibiotics to help maintain the health of ant fungus gardens.

To examine this hypothesis, Currie et al (24) conducted extensive bioassays between attine ant-associated actinomycetes and an ecologically relevant (i.e. species that fungus gardens might be exposed to) and taxonomically diverse group of fungi. They determined that the bacterium apparently does not produce secondary metabolites with any general antifungal properties. However, these bacteria do produce specialized antibiotics that have potent inhibitory properties against the pathogen Escovopsis (24). Producing antibiotics is energetically costly and requires complex and genetically based physiological adaptations; thus, when present, antibiotics are assumed to impart a substantial selective advantage to the producer. Therefore the production of antibiotics with specific activity against the specialized pathogen Escovopsis is strong evidence that the actinomycete is a highly evolved mutualist within this ancient association, utilized by fungusgrowing ants to suppress Escovopsis (Figure 3).

Experimental evidence of the benefit of the actinomycete to fungus-growing ants and their fungi has been established. C.R. Currie, A.N.M. Bot \& J.J. Boomsma (submitted) conducted an experiment crossing the presence/absence of the actinomycete with the presence/absence of the parasite Escovopsis using subcolonies of Acromyrmex octospinosus. They found an increase in the abundance and impact of the pathogen within infected gardens in those sub-colonies with the bacterium removed from workers. In addition, they established, as would be expected based on the apparent importance of the bacterium in helping protect the garden from Escovopsis, that the actinomycete is more abundant on workers that are specialized to tend the garden than those that are specialized to forage (C.R. Currie, A.N.M. Bot, \& J.J. Boomsma, manuscript submitted). 


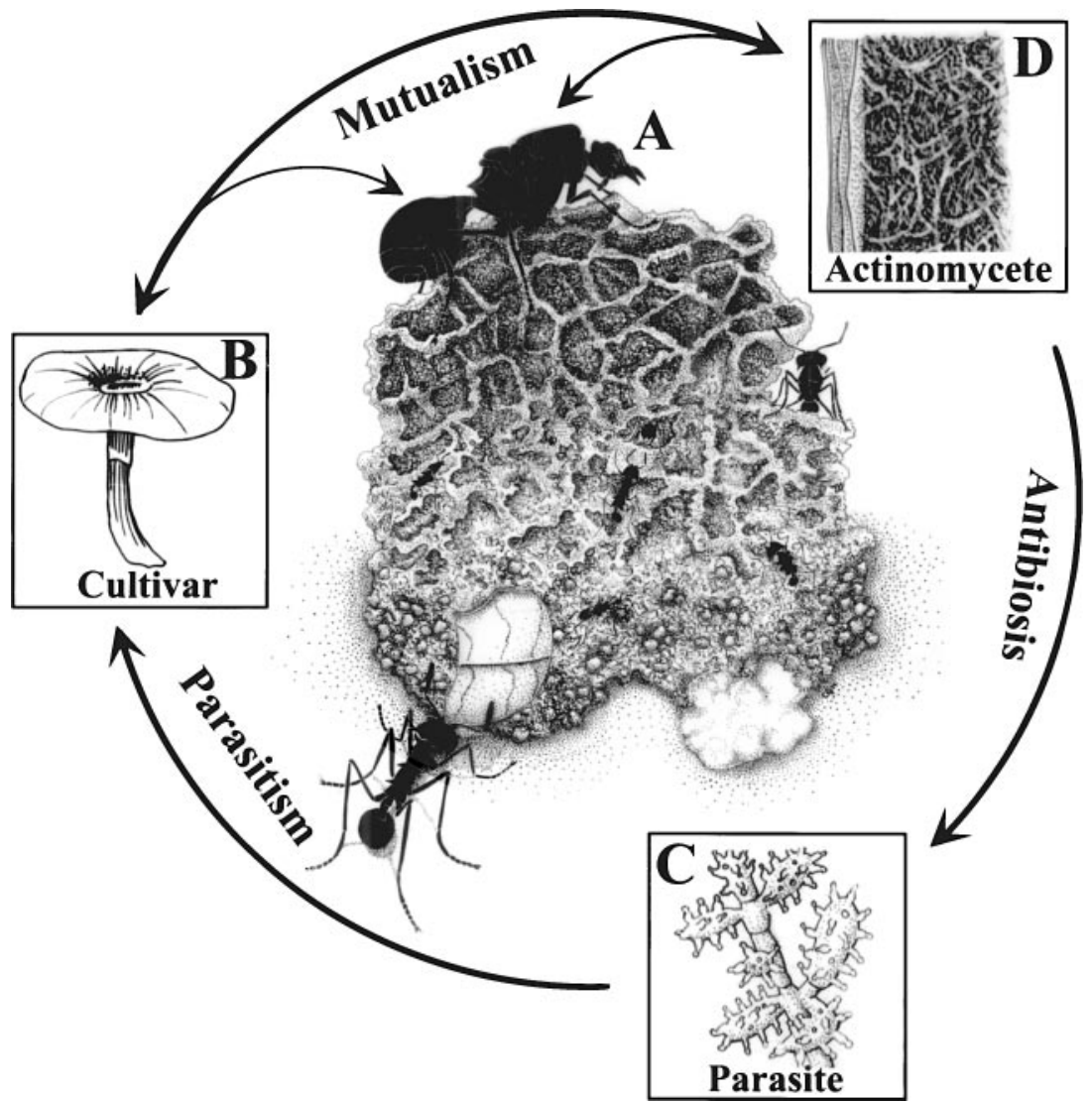

Figure 3 Pictorial representation of the quadripartite symbiosis. (A) The large-body queen represents the fungus-growing ants. (B) The mushroom depicts the fungus the ants cultivate and has the appearance of free-living leucocoprineous fungi. (C) The microfungus in the box represents the garden parasite Escovopsis. (D) The final illustration represents the actinomycete that grows on the cuticle of fungus-growing ants and produces antibiotics that suppress the growth of Escovopsis. Arrows represent interacting components: Double-headed arrows represent mutualistic association and single-headed arrows represent a negative interaction. The original line drawing was created by Cara Gibson.

The actinomycete appears to provide at least two additional benefits to the fungal cultivars and ants. First, Currie et al (24) showed, in at least one genus of fungus-growing ants (Apterostigma), a substantial increase in the growth of the ants' cultivars when grown in broth cultures with filtrate from the bacterium. This suggests that the bacterium may produce growth-promoting compounds for the cultivars within gardens. It is not currently clear what compounds are produced, and growth promotion within gardens (as opposed to within broth cultures) remains to be established. Second, the bacterium may also protect the ants themselves from 
pathogens. The bacterium can completely cover the cuticle of workers and queens (Figure $2 b$ ) and thus may serve as a barrier against insect pathogens that must penetrate the exoskeleton of workers to establish infection $(17,79)$. It is also possible that the bacterium produces antibiotics against entomopathogenic fungi. Bioassays by Currie et al (24) between general entomopathogenic fungi and the fungus-growing ant-associated actinomycete revealed no such activity. However, it is possible that these actinomycetes produce potent antibiotics against specialized entomopathogens. Entomopathogenic fungi occasionally have been noted from attine ants $(39,68,73)$, although no specialized pathogens of the ants have been identified.

\section{Benefit to the Actinomycete}

The bacterium associated with fungus-growing ants appears to obtain several benefits from this mutualistic association. First, as previously noted, virgin queens disperse the bacterium by carrying it with them on their nuptial flight. Second, the abundant and diverse assemblage of attine ants provides these bacteria with a unique habitat; because actinomycetes are not commonly associated with insects, the evolution of a symbiotic association with a tribe of ants provides a completely unoccupied niche. It is currently not clear how the actinomycete obtains nourishment for growth, but it does not appear to penetrate the cuticle of the ants (C.R. Currie, unpublished data). Fungus-growing ants apparently are able to promote the growth of the actinomycete, because workers in Acromyrmex octospinosus subcolonies experimentally infected with the pathogen Escovopsis had more actinomycete on their cuticle eight days after infection than workers in uninfected subcolonies (C.R. Currie, A.N.M. Bot, \& J.J. Boomsma, manuscript submitted). This promotion of actinomycete growth may occur through the secretion of nutrients for the growth of the bacterium by the ants, perhaps through a gland. Some fungusgrowing ants have structures that appear to be modified to provide a location for the bacterium, and it is possible that these structures are associated with glands that produce nutrients for the bacterium's growth (C.R. Currie, unpublished data).

\section{FUTURE DIRECTIONS}

The identification of two additional symbionts, a highly evolved garden pathogen and a third mutualist that suppresses the growth of this pathogen, generates many new questions in this well-studied symbiosis. The most pressing of these issues may be the apparent absence of resistance to the antibiotics produced by the antassociated actinomycetes in Escovopsis. Sixty years of antibiotic use by humans has already resulted in widespread resistance in microbes. Escovopsis apparently has been exposed to the antibiotics produced by the ant-associated actinomycetes for millions of years. Future work on this association should attempt to determine whether the evolution of antibiotic resistance is indeed rare in Escovopsis, and if so, how the combined activities of the ants, their fungal cultivars, and the actinomycete 
result in the inability of the pathogen to readily evolve resistance. An understanding of the dynamics of this association could provide important new insights into our own development and use of these incredibly important human pharmaceuticals $(24,71)$.

As outlined in this review, recent studies comparing the evolutionary history of the ants and their fungal cultivars have revealed a complex association between these two mutualists $(16,56)$. By determining the evolutionary history of these two additional symbionts and incorporating them with those of the ants and their fungi, it will be possible to examine how all four symbionts have been coevolving with one other. For example, when the ants and their fungal cultivars have incongruence in their evolutionary history, does the evolutionary history of Escovopsis match-up with that of the fungal cultivars or with that of the ants? Does the evolutionary history of the actinomycete match that of the ants (which transmit it), of the fungal cultivars (which it protects), or of Escovopsis (which it defends against)? Attempts to answer these questions should not only provide new insights into the dynamics of this ancient association but also into symbiosis in general.

In this review I have attempted to illustrate how utilizing a multilateral approach to the study of mutualism results in a more complete understanding of symbiosis. However, I have limited my discussion to the ants, the fungal cultivars, Escovopsis, and the actinomycete. Although no other organism has been shown to occur throughout the phylogenetic diversity of the mutualism, the recent discovery of two new symbionts suggests that other players are likely involved. Some promising candidates include other microbes, such as bacteria and yeast, and some of the diverse assemblage of invertebrates that have been observed to be associated with fungus-growing ant colonies.

\section{CONCLUDING REMARKS}

The ancient and highly evolved association between fungus-growing ants and their fungi is a textbook example of mutualism and a model system in the study of symbiosis (22). Research on this system has resulted in the publication of thousands of scientific articles (18). However, despite the attention that this mutualism has received by biologists, it is now obvious that the complexity of this mutualism has been greatly underestimated. First, the gardens of fungus-growing ants have been found to be parasitized by a virulent fungal parasite in the genus Escovopsis. In addition, a third mutualist was recently discovered within this symbiosis, a filamentous bacterium that produces antibiotics that suppress the growth of the specialized parasite Escovopsis (Figure 3). The overlooked complexity of associations within this extensively studied mutualism suggests that similar complex symbiotic interactions are also currently unknown, even in other well-known systems. These findings indicate that microbes and their metabolites may regulate the interactions of additional highly evolved symbioses. Thus, a multilateral approach may be essential to better understand mutualisms, as well as symbioses more generally. 


\section{ACKNOWLEDGMENTS}

I thank G. Currie, M. Kweskin, N. Mehdiabadi, and T. Murakami for insightful comments on this manuscript. I acknowledge the Microscopy Facility of the Institute for Cellular Molecular Biology at the University of Texas for use of their SEM and John Mendenhall for help creating the micrograph used in Figure $2 a$. Special thanks to Christian Ziegler for the use of his photograph in Figure $2 b$ and Cara Gibson for the use of her line drawing in Figure 3. I was provided financial support during the writing of this review from a Natural Sciences and Engineering Research Council postdoctoral fellowship and NSF CAREER grant DEB-9983879 awarded to U.G. Mueller.

\section{Visit the Annual Reviews home page at www.AnnualReviews.org}

\section{LITERATURE CITED}

1. Adams RMM, Mueller UG, Holloway AK, Green AM, Narozniak J. 2001. Garden sharing and garden stealing in fungusgrowing ants. Naturwissenschaften 87: 491-93

2. Agrios GN. 1988. Plant Pathology. San Diego, CA: Academic. 803 pp.

3. Ahmadjian V, Paracer S. 1986. Symbiosis: An Introduction to Biological Associations. London: University Press of New England

4. Angeli-Papa J. 1984. La culture d'un champignon par les fourmis attines. Cryptogam. Mycol. 5:147-54

5. Autuori M. 1941. Contribuicao para o conhecimento da sauva (Atta spp.). I. Evolucao do sauveiro (Atta sexdens rubropilosa Forel, 1908). Arq. Inst. Biol. Sao Paulo 12:197-228

6. Barrett JA. 1981. The evolutionary consequences of monoculture. In Genetic Consequences of Man-Made Change, ed. JA Bishop, LM Cook, pp. 209-48. London: Academic

7. Bass M, Cherrett JM. 1994. The role of leaf-cutting ant workers (Hymenoptera: Formicidae) in fungus garden maintenance. Ecol. Entomol. 19:21520

8. Bass M, Cherrett JM. 1996. Leaf-cutting ants (Formicidae, Attini) prune their fun- gus to increase and direct its productivity. Funct. Ecol. 10:55-61

9. Beattie AJ, Turnbull C, Hough T, Jobson S, Knox RB. 1985. The vulnerability of pollen and fungal spores to ant secretions: evidence and some evolutionary implications. Am. J. Bot. 72:606-14

10. Beattie AJ, Turnbull C, Hough T, Knox RB. 1986. Antibiotic production: a possible function for the metapleural glands of ants (Hymenoptera: Formicidae). Ann. Entomol. Soc. Am. 79:448-50

10a. Bot ANM, Currie CR, Hart AG, Boomsma JJ. 2001. Waste management in leafcutting ants. Ethol. Ecol. Evol. In press

11. Boucher DH, ed. 1985. The Biology of Mutualism: Ecology and Evolution. New York: Oxford Univ. Press

12. Boucher DH, James S, Keeler KH. 1982. The ecology of mutualism. Annu. Rev. Ecol. Syst. 13:315-47

13. Boyd ND, Martin MM. 1975. Faecal proteinases of the fungus-growing ant Atta texana: properties, significance, and possible origin. Insect Biochem. 5:619-35

14. Bronstein JL. 1994. Our current understanding of mutualism. Q. Rev. Biol. 69:31-51

15. Carreiro SC, Pagnocca FC, Bueno OC, Bacci M Jr, Hebling MJA, da Silva OA. 1997. Yeasts associated with nests of the 
leaf-cutting ant Atta sexdens rubropilosa Forel, 1908. Anthonie van Leeuwenhoek J. Microbiol. Serol. 71:243-48

16. Chapela IH, Rehner SA, Schultz TR, Mueller UG. 1994. Evolutionary history of the symbiosis between fungus-growing ants and their fungi. Science 266:1691-94

17. Charnley AK. 1984. Physiological aspects of destructive pathogenesis in insects by fungi: a speculative review. In Invertebrate-Microbial Interactions, $\mathrm{Br}$. Mycol. Soc. Symp. 6, ed. JM Anderson, ADM Rayner, DWH Walton, pp. 229-70. London: Cambridge Univ. Press

18. Cherrett JM. 1986. The history of the leafcutting ant problem. See Ref. 42a, pp. 1017

19. Craven SE, Dix MD, Michaels GE. 1970. Attine fungal gardens contain yeasts. Science 169:184-86

20. Currie CR. 2000. The ecology and evolution of a quadripartite symbiosis: examining the interactions among attine ants, fungi, and actinomycetes, $\mathrm{PhD}$. thesis. Dep. Botany, Univ. Toronto

21. Currie CR. 2001. Prevalence and impact of a virulent parasite on a tripartite mutualism. Oecologia 128:99-106

22. Currie CR. 2001. Ants, agriculture, and antibiotics: a quadripartite symbiosis. In Symbiosis, ed. J Seckbach. Dordrecht, The Netherlands: Kluwer Academic. In press

23. Currie CR, Mueller UG, Malloch D. 1999. The agricultural pathology of ant fungus gardens. Proc. Natl. Acad. Sci. USA 96:7998-8002

24. Currie CR, Scott JA, Summerbell RC, Malloch D. 1999. Fungus-growing ants use antibiotic-producing bacteria to control garden parasites. Nature 398:701-4

24a. Currie CR, Stuart AE. 2001. Weeding and grooming of pathogens in agriculture by ants. Proc. R. Soc. London Ser. B 268: 1033-39

25. Dennis RWG. 1952. Lepiota and allied genera in Trinidad, British West Indies. Kew Bull. 7:459-99

26. Ebert D, Hamilton WD. 1996. Sex again- st virulence: the coevolution of parasitic diseases. TREE 11:79-82

27. Eisner T, Happ GM. 1962. The infrabuccal pocket of a formicine ant: a social filtration device. Psyche 69:107-16

28. Fisher PJ, Stradling DJ, Sutton BC, Petrini LE. 1996. Microfungi in the fungus gardens of the leaf-cutting ant Atta cephalotes: a preliminary study. Mycol. Res. 100:541-46

29. Goodfellow M, Cross T. 1984. The Biology of Actinomycetes. London: Academic

30. Hervey A, Nair MSR. 1979. Antibiotic metabolite of a fungus cultivated by gardening ants. Mycologia 71:1064-66

31. Hervey A, Rogerson CT, Leong I. 1977. Studies on fungi cultivated by ants. Brittonia 29:226-36

32. Hinkle G, Wetterer JK, Schultz TR, Sogin ML. 1994. Phylogeny of the attine fungi based on analysis of small subunit ribosomal RNA gene sequences. Science 266:1695-97

33. Hölldobler B, Engel-Siegel H. 1984. On the metapleural gland of ants. Psyche 91:201-24

34. Hölldobler B, Wilson EO. 1990. The Ants. Cambridge, MA: Belknap

35. Huber J. 1905. Uber die Koloniegrundung bei Atta sexdens L. Biol. Zentrabl. 25: 606-19

36. Ihering von H. 1898. Die anlage neuer Colonien und Pilzgarten bei Atta sexdens. Zool. Anz. 21:238-45

37. Jaenike J. 1978. A hypothesis to account for the maintenance of sex within populations. Evol. Theory 3:191-94

38. Kermarrec A, Febvay G, Decharme M. 1986. Protection of leaf-cutting ants from biohazards: Is there a future for microbiological control? See Ref. 42a, pp. 339-55

39. Kermarrec A, Mauleon H. 1975. Quelques aspects de la pathogenie d' Entomophthora coronata Cost. Kervork pour la fourmi maioc de la Guadeloupe, Acromyrmex octospinosus (Formicidae: Attini). Ann. Parasitol. 50:351-60

40. Knapp JJ, Jackson CW, Howse PE, 
Vilela EF. 1994. Mandibular gland secretions of leaf-cutting ants: role in defense against alien fungi. In 12th Congress of the International Union for the Study of Social Insects, ed. A Lenoir, F Arnold, M Lepage, p. 109. Paris: Univ. Paris

41. Kreisel H. 1972. Pilze aus Pilzgärten von Atta insularis in Kuba. Z. Allg. Mikrobiol. 12:643-54

42. Littledyke M, Cherrett JM. 1976. Direct ingestion of plant sap from cut leaves by the leaf-cutting ants Atta cephalotes (L.) and Acromyrmex octospinosus (Reich) (Formicidae, Attini). Bull. Ent. Res. 66:205-17

42a. Lofgren CS, Vander Meer RK, eds. 1986. Fire Ants and Leaf-Cutting Ants. Boulder, CO: Westview

43. Lucas GB. 1980. The war against blue mold. Science 210:147-53

44. Martin MM. 1970. The biochemical basis of the fungus-attine ant symbiosis. Science 169:16-20

45. Martin MM. 1987. Invertebrate-Microbial Interactions. Ithaca, NY: Cornell Univ. Press

46. Martin MM, MacConnell JG, Gale GR. 1969. The chemical basis for the attine ant-fungus symbiosis. Absence of antibiotics. Ann. Entomol. Soc. Am. 62:38688

47. Martin MM, Martin JS. 1970. The biochemical basis for the symbiosis between the ant, Atta colombica tonsiper, and its food fungus. J. Insect Phys. 16:109-19

48. Maschwitz U, Koob K, Schildknecht H. 1970. Ein Beitrag zur Funktion der Metathoracaldruse der Amerisen. J. Insect Phys. 16:387-404

49. Maynard Smith J. 1978. The Evolution of Sex. Cambridge: Cambridge Univ. Press

50. Margulis L, Fester R, eds. 1991. Symbiosis as a Source of Evolutionary Innovation: Speciation and Morphogenesis. Cambridge, MA: MIT Press

51. Maynard Smith J, Szathmáry E. 1995. The Major Transitions in Evolution. Oxford: Freeman
52. Möller AFW. 1893. Die Pilzgärten Einiger Südamerikanischer Ameisen. Jena, Ger.: Fischer

53. Moncalvo JM, Lutzoni FM, Rehner SA, Johnson J, Vilgalys R. 2000. Phylogenetic relationship of agaric fungi based on large ribosomal subunit DNA sequences. Syst. Biol. 49:278-305

54. Muchovej JJ, Della Lucia TMC. 1990. Escovopsis, a new genus from leaf-cutting ant nests to replace Phialocladus nomen invalidum. Mycotaxon 37:191-95

55. Muchovej JJ, Della Lucia TMS, Muchovej RMC. 1991. Leucoagaricus weberi sp. nov. from a live nest of leaf-cutting ants. Mycol. Res. 95:1308-11

56. Mueller UG, Rehner SA, Schultz TR. 1998. The evolution of agriculture in ants. Science 281:2034-38

57. Mueller UG, Schultz TR, Currie CR, Adams RMM, Malloch D. 2001. The origin of the attine ant-fungus mutualism. $Q$. Rev. Biol. 76:169-97

58. Mueller UG, Wcislo WT. 1998. Nesting biology of the fungus-growing ant Cyphomyrmex longiscapus Weber (Attini, Formicidae). Insectes Soc. 45:181-89

59. Murakami T, Higashi S. 1997. Social organization in two primitive attine ants, Cyphomyrmex rimosus and Myrmicocrypta ednaella, with reference to their fungus substrates and food sources. $J$. Ethol. 15:17-25

60. Nascimento RRD, Schoeters E, Morgan ED, Billen J, Stradling DJ. 1996. Chemistry of metapleural gland secretions of three attine ants, Atta sexdens rubopilosa, Atta cephalotes, and Acromyrmex octospinosus. J. Chem. Ecol. 22:9871000

61. North RD, Jackson CW, Howse PE. 1997. Evolutionary aspects of ant-fungus interactions in leaf-cutting ants. TREE 12:38689

62. Ortius-Lechner D, Maile R, Morgan ED, Boomsma JJ. 2000. Metapleural gland secretion of the leaf-cutter ant Acromyrmex octospinosus: new compounds and their 
functional significance. J. Chem. Ecol. 26:1667-83

63. Papa J, Papa F. 1982. Etude de l'activité microbiologique dans les nids d'Acromyrmex octospinosus Reich en Guadeloupe. Bull. Soc. Pathol. Exot. 75:40414

64. Price PW, Westoby M, Rice B, Atsatt PR, Fritz RS, et al. 1986. Parasite mediation in ecological interactions. Annu. Rev. Ecol. Syst. 17:487-505

65. Quinlan RJ, Cherrett JM. 1977. The role of substrate preparation in the symbiosis between the leaf-cutting ant Acromyrmex octospinosus (Reich) and its food fungus. Ecol. Entomol. 2:161-70

66. Quinlan RJ, Cherrett JM. 1978. Aspects of the symbiosis of the leaf-cutting ant Acromyrmex octospinosus and its food fungus. Ecol. Entomol. 3:221-30

67. Quinlan RJ, Cherrett JM. 1979. The role of the fungus in the diet of the leafcutting ant Atta cephalotes. Ecol. Entomol. 4:151-60

68. Samson RA, Evans HC, Latgé JP. 1988. Atlas of Entomopathogenic Fungi. Berlin: Springer-Verlag

69. Schildknecht H, Koob K. 1970. Plant bioregulators in the metathoracic glands of myrmicine ants. Angew. Chem. Int. Ed. Engl. 9:173

70. Schildknecht H, Koob K. 1971. Myrmicacin, the first insect herbicide. Angew. Chem. Int. Ed. Engl. 10:124-25

71. Schultz TR. 1999. Ants, plants and antibiotics. Nature 398:747-48

72. Schultz TR, Meier RA. 1995. A phylogenetic analysis of the fungus-growing ants (Hymenoptera: Formicidae: Attini) based on morphological characters on the larvae. Syst. Entomol. 20:337-70

73. Schmid-Hempel P. 1998. Parasites in Social Insects. Princeton, NJ: Princeton Univ. Press

74. Seger J, Hamilton WD. 1988. Parasites and sex. In The Evolution of Sex, ed. RE Michod, BR Levin, pp. 176-93. Sunderland, UK: Sinauer
75. Seifert KA, Samson RA, Chapela IH. 1995. Escovopsis aspergilloides, a rediscovered hyphomycete from leaf-cutting ant nests. Mycologia 87:407-13

76. Singer R. 1986. The Agaricales in Modern Taxonomy. Königstein, Ger.: Költz Scientific Books

77. Stahel G, Geijskes DC. 1939. Ueber den Bau der Nester von Atta cephalotes (L.) und Atta sexdens (L.) (Hym: Formicidae). Revista. Ent. Rio J. 10:27-78

78. Stahel G, Geijskes DC. 1941. Weitere Untersuchungen über Nestbau und Gartenpilz von Atta cephalotes L. und Atta sexdens L. (Hym. Formicidae). Rev. Entomol. 12:243-68

79. St. Leger RJ. 1991. Integument as a barrier to microbial infections. In Physiology of the Insect Epidermis, ed. K Binnington, A Retnakaran, pp. 284-306. Melbourne, Aust.: CSIRO

80. Stradling DJ, Powell RJ. 1986. The cloning of more highly productive fungal strains: a factor in the speciation of fungus-growing ants. Experientia 42:962-64

81. Van Valen L. 1973. A new evolutionary law. Evol. Theory 1:1-30

82. Veal DA, Trimble JE, Beattie AJ. 1992. Antimicrobial properties of secretions from the metapleural glands of Myrmecia gulosa (the Australian bull ant). J. Appl. Bacteriol. 72:188-94

83. Waksman SA, Lechevalier HA. 1962. The Actinomycetes, vol. III. Antibiotics of Actinomycetes. Baltimore: Williams \& Wilkins

84. Wang Y, Mueller UG, Clardy J. 1999. Antifungal diketopiperazines from symbiotic fungus of fungus-growing ant Cyphomyrmex minutus. J. Chem. Ecol. 25:935-41

85. Weber NA. 1955. Pure cultures of fungi produced by ants. Science 121:109

86. Weber NA. 1957. Weeding as a factor in fungus culture by ants. Anat. Rec. 128:638

87. Weber NA. 1966. The fungus-growing ants. Science 121:587-604 
88. Weber NA. 1972. Gardening Ants: The Attines. Philadelphia: Am. Philos. Soc.

89. Weber NA. 1979. Fungus culturing by ants. In Insect Fungus Symbiosis, Mutualism and Commensalism, ed. LR Batra. New York: Allanheld, Osmun \& Co/Halsted Press

90. Wetterer JK, Schultz TR, Meier R. 1998. Phylogeny of fungus-growing ants (tribe Attini) based on mtDNA sequence and morphology. Mol. Phylogenet. Evol. 9: 42-47

91. Wheeler WM. 1910. Ants: Their Structure, Development, and Behavior. New York: Columbia Univ. Press

92. Williams GC. 1975. Sex and Evolution. Princeton, NJ: Princeton Univ. Press

93. Wilson EO. 1971. The Insect Societies. Cambridge, MA: Belknap Harvard Univ. Press 


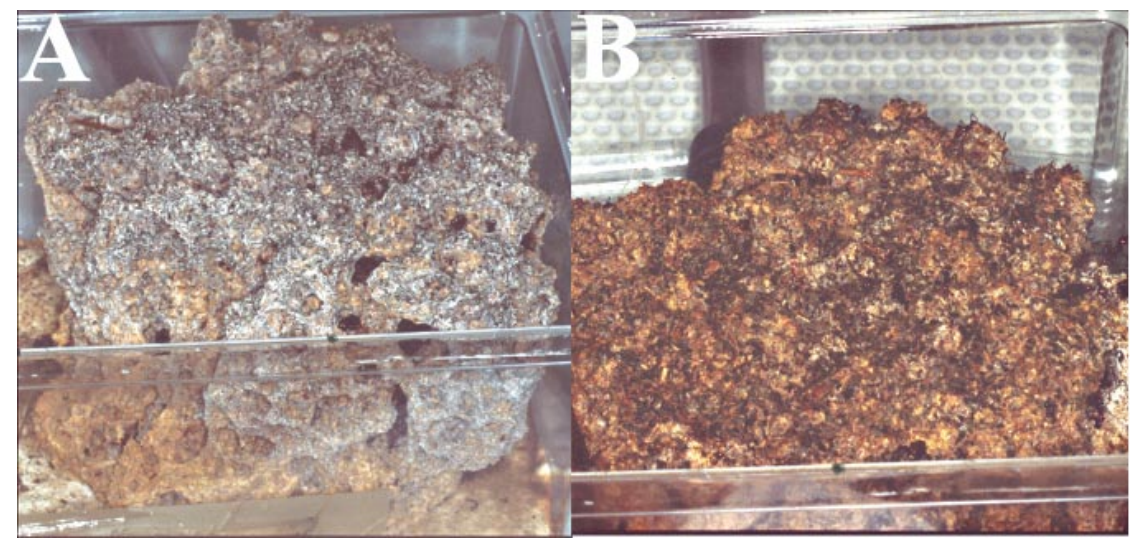

Figure 1 A fungus garden of Atta cephalotes. (A) Photograph of a healthy garden maintained in the laboratory at the University of Toronto for more than a year and a half. $(B)$ Photograph of the same garden 10 days after being experimentally infected with the garden pathogen, Escovopsis. The garden shown here is in the final stages of infection and has been abandoned by the ants. Fungal growth is no longer apparent, as the garden matrix has become dry and the garden has died. 

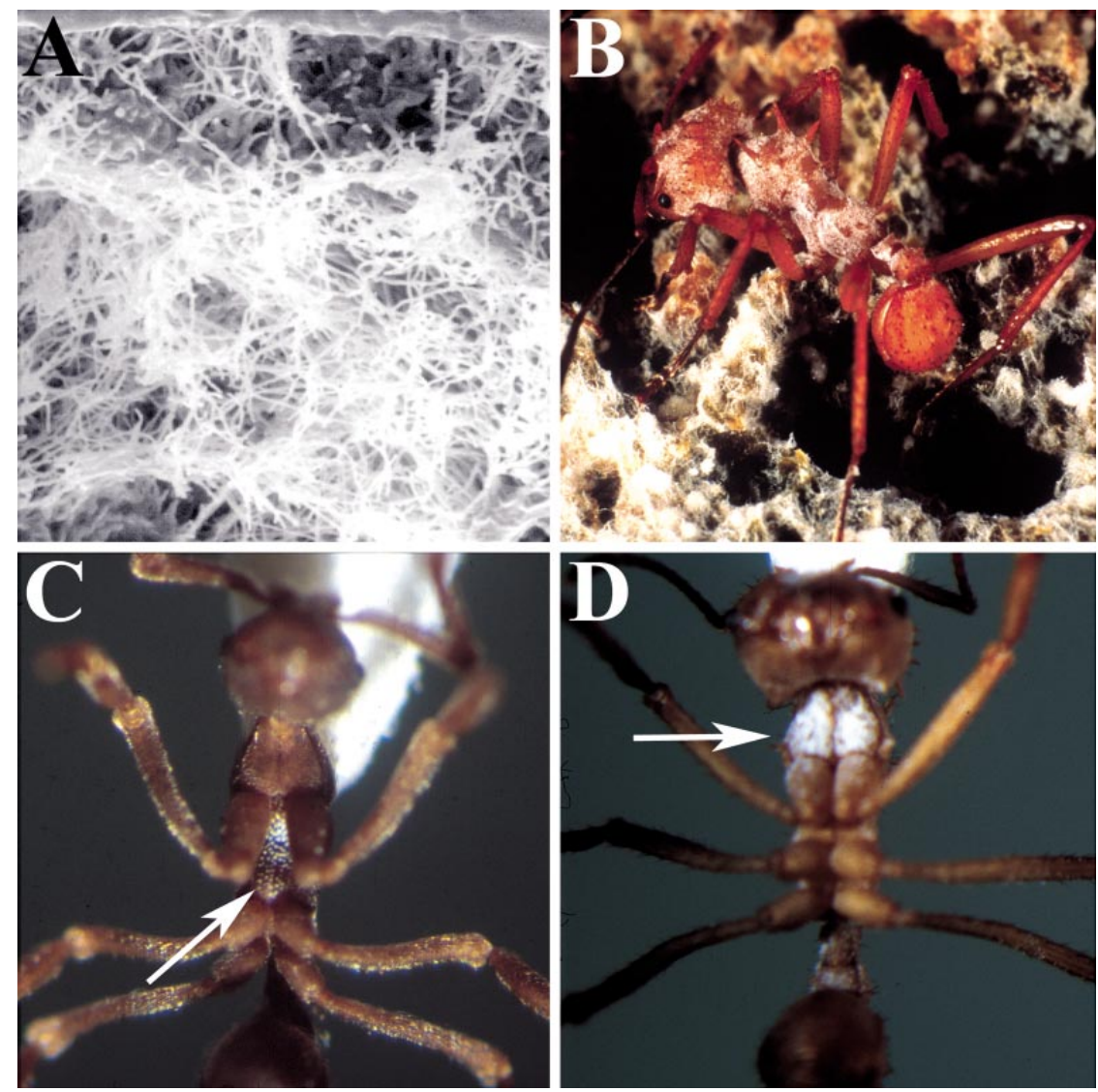

Figure 2 A micrograph and three photographs showing the presence of the symbiotic actinomycete on the cuticle of fungus-growing ants. (A) Micrograph illustrating the thick filamentous growth of the bacterium on the surface of Acromyrmex octospinosus. (B) Photograph of an A. octospinosus worker tending the garden, illustrating the thick whitish-gray coating of actinomycete over most of the thorax and head of the worker. (Photograph was taken by Christian Ziegler.) $(C)$ Ventral view of Apterostigma spp., illustrating the actinomycete growing under the forelegs of the worker (arrow), as occurs in the most phylogenetically basal genera. (D) Ventral view of A. octospinosus, illustrating the concentration of actinomycete growth in front of the forelegs (arrow), as occurs in the more phylogenetically derived genera. 
R

Volume 55, 2001

\section{CONTENTS}

FRONTISPIECE, John L. Ingraham

LEARNING TO FLY FISH, John L. Ingraham

xii

Roles of ThIOL-Redox PATHWAYs IN BACTERIA, Daniel Ritz and Jon Beckwith

BACTERIAl GLiding Motility: Multiple Mechanisms FOR CELl MOVEMENT OVER SuRfaCeS, Mark J. McBride

TOXIC SHOCK SYNDROME AND BACTERIAL SUPERANTIGENS:

AN UPDATE, John K. McCormick, Jeremy M. Yarwood, and

Patrick M. Schlievert

BIG BACTERIA, Heide N. Schulz and Bo Barker Jorgensen

NONREPLICATING PERSISTENCE OF MYCOBACTERIUM TUBERCULOSIS, Lawrence G. Wayne and Charles D. Sohaskey

QUORUM SENSING IN BACTERIA, Melissa B. Miller and Bonnie L. Bassler

ADVANCES IN THE BACTERIOLOGY OF THE COLIFORM GROUP: THEIR Suitability AS MARKERS OF Microbial WATER SAFETy, H. Leclerc, D. A. A. Mossel, S. C. Edberg, and C. B. Struijk

BiologicAl WEAPONS-A PRIMER FOR MiCROBIOLOGISTS, Robert J. Hawley and Edward M. Eitzen, Jr.

VIRUSES AND INTERFERONS, Ganes $C$. Sen

PHAGES OF DAIRY BACTERIA, Harald Brüssow

BACTERIAL FATTY ACID BIOSYNTHESIS: TARGETS FOR ANTIBACTERIAL DRUG DisCOVERY, John W. Campbell and John E. Cronan, Jr.

Novel Thiols of Prokaryotes, Robert C. Fahey

A COMMUNity of ANTS, Fungi, AND BACTERIA: A Multilateral APPROACH TO STUDYING SYMBIOSIS, Cameron R. Currie

Homology-DEPENDENT GENE SilENCING MECHANISMS

IN FUnGI, Carlo Cogoni

INTERACTION OF BACTERIAL PATHOGENS WITH POLARIZED

EPITHELIUM, B. I. Kazmierczak, K. Mostov, and J. N. Engel

BACTERIOPHAGE THERAPY, William C. Summers 
Molecular Aspects of Parasite-Vector AND Vector-Host INTERACTIONS IN LEISHMANIASIS, David Sacks and Shaden Kamhawi

AMMONIA-OXIDIZING BACTERIA: A MODEL FOR MOLECULAR Microbial ECOLOGY, George A. Kowalchuk and John R. Stephen

IMMUNE CHECKPOINTS IN VIRAL LATENCY, Stella Redpath, Ana Angulo, Nicholas R. J. Gascoigne, and Peter Ghazal

RECOMBINATION AND THE POPULATION STRUCTURES OF BACTERIAL PATHOGENS, Edward J. Feil and Brian G. Spratt

PeriPlasmic STRESS AND ECF Sigma FACTORS, Tracy L. Raivio and Thomas J. Silhavy

Hydrophobins: Multipurpose Proteins, Han A. B. Wösten

ANTHRAX, Michèle Mock and Agnès Fouet

ANTIGENIC VARIATION AT THE INFECTED RED CELL SURFACE In Malaria, Sue Kyes, Paul Horrocks, and Chris Newbold

HORIZONTAL GENE TRANSFER IN PROKARYOTES: QUANTIFICATION AND ClassifiCATION, Eugene V. Koonin, Kira S. Makarova, and L. Aravind

Aspects of Fungal Pathogenesis In Humans, Jo-Anne H. van Burik and Paul T. Magee

INDEXES

Subject Index

773

Cumulative Index of Contributing Authors, Volumes 51-55

Cumulative Index of Chapter Titles, Volumes 51-55

\section{ERRATA}

An online log of corrections to Annual Review of Microbiology chapters (if any have yet been occasioned, 1997 to the present) may be found at http://micro.AnnualReviews.org 